\title{
Synthesis of Metallated (Cu, Pd) Crown Substituted Tetracyclohexenoporphyrins. Crown-Containing Pd Tetrabenzoporphyrin and Its Phosphorescence
}

\author{
Ksenia V. Tikhomirova, Denis E. Chumakov, Andrey V. Khoroshutin, ${ }^{@}$ \\ and Alexander V. Anisimov
}

M. V. Lomonosov Moscow State University, 119991 Moscow, Russia

${ }^{\circledR}$ Corresponding author E-mail: khorosh@petrol.chem.msu.ru

\begin{abstract}
Palladium and copper tetracyclohexenoporphyrins (cyclohexano rings annelated to pyrrole rings), tri-mesophenylsubstituted and mono-meso-substituted with benzo-15-crown-5 ether moiety (PdPh_[benzo-15-crown-5]TCP and $\mathrm{CuPh}_{3}$ [benzo-15-crown-5]TCP) have been synthesized. Coupling of 1,1-(arylmethylene)bis-4,5,6,7-tetrahydro$2 \mathrm{H}$-isoindole with the corresponding aldehyde in Lindsey conditions has been used. Two variations of the reagents combinations have been tested. Phenyl substituted dipyrromethane reacted with the mixture of m-formylbenzo-15-crown-5 and benzaldehyde gave the best cyclization results. Separation of the mixture of the scrambled products was greatly enhanced by metallation prior to column chromatography, thus rendering the yields of PdPh $[$ benzo-15-crown-5]TCP and $\mathrm{CuPh}_{3}$ [benzo-15-crown-5]TCP $16 \%$ and $18 \%$ respectively. An alternative combination of the reagents, i.e. benzo15-crown-5-substituted isoindole and benzaldehyde, afforded no porphyrin products besides $\mathrm{H}_{2} \mathrm{Ph}_{4} \mathrm{TCP}$. Oxidation of $\mathrm{PdPh}_{3}\left[\right.$ benzo-15-crown-5]TCP by DDQ yielded the corresponding tetrabenzoporphyrin (PdPh ${ }_{3}[$ benzo-15-crown-5] TBP) in 71\%. Phosphorescence spectrum of the latter has been studied.
\end{abstract}

Keywords: Synthesis, tetracyclohexenoporphyrin, tetrabenzoporphyrin, 15-crown-5, palladium, copper, dipyrromethanes, phosphorescence.

\section{Синтез металлированных $(\mathrm{Cu}, \mathrm{Pd})$ краунсодержащих тетрациклогексенопорфиринов. Синтез и фосфоресценция краунированного тетрабензопорфирина Pd}

\author{
К. В. Тихомирова, А. Э. Чумаков, А. В. Хорошутин, ${ }^{\circledR}$ А. В. Анисимов \\ Московский государственный университет им. М.В. Ломоносова, 119991 Москва, Россия \\ ${ }^{\circledR}$ E-mail: khorosh@petrol.chem.msu.ru
}

\begin{abstract}
На основе реакций конденсации тетрагидроизоиндола и производных дипиррометанов с ароматическими альдегидами синтезированы новые мезо-бензокраунтетрациклогексенопорфирины палладия и меди, а также синтезирован неизвестный ранее мезо-бензокраун-тетрабензопорфирин палладия. Исследованы оптические свойства полученных соединений.
\end{abstract}

Ключевые слова: Синтез, тетрациклогексенопорфирин, тетрабензопорфирин, 15-краун-5, палладий, медь, дипиррометаны, фосфоресценция.

\section{Введение}

Тетрабензопорфирины (ТБП), в которых присутствуют ароматические фрагменты, аннелированные к пиррольным кольцам порфирина, представляют интерес в связи со значительно смещёнными в красную область полосами Сорэ и $Q$-полосами и многократным увеличением коэффициента экстинкции последней. Интересные фотофизические свойства таких молекул дают им преимущество в ряде приложений. ${ }^{[1-4]}$ Внимание к этим соединениям во многом обусловлено развитием новых методов их синтеза на основе низкотемпературной циклизации, ${ }^{[5-8]}$ в дополнение к развивающимся «высокотемпературным» методам. ${ }^{[9-12]}$ Низкотемпера- 
турные методы дают дополнительные возможности варьирования в широком пределе арилзаместителей в мезо-положениях.

Среди примеров таких заместителей, однако, отсутствуют краунсодержащие, несмотря на то, что аналогичные нерасширенные краун-порфирины довольно давно известны. ${ }^{[13,14]}$ Последние обладают способностью образовывать комплексы с катионами металлов и органическими молекулами по двум координационным центрам: порфириновому ядру и краун-эфирному фрагменту, что отражается в изменении ряда их свойств. Эта особенность открывает возможности для их применения в качестве сенсоров на катионы щелочных и щелочноземельных металлов ${ }^{[15]}$ и органические молекулы, ${ }^{[16]}$ компонентов каталитических систем, ${ }^{[17]}$ моделей для изучения процессов переноса электронов и энергии, ${ }^{[18]}$ фотосинтеза, ${ }^{[19]}$ а также для создания высокоупорядоченных самоорганизующихся супрамолекулярных систем. ${ }^{[20,21]}$

Целью данной работы являлся синтез тетрабензопорфиринов и их предшественниковтетрациклогексенопорфиринов, содержащих бензокраун-эфирные фрагменты в мезо-положениях, а также исследование их оптических свойств.

\section{Экспериментальная часть}

Растворители, а также эфират трёхфтористого бора и моногидрат ацетата меди, приобретали у фирмы Реахим. Растворители предварительно перегонялись согласно стандартным методикам. Бензальдегид, $n$-толуолсульфокислоту и 4-формилбензо-15-краун-5 2 приобретали у фирмы Aldrich. Хлорид тетрабутиламмония, DDQ, триэтиламин и хлорид палладия были приобретены у Acros Organics. Этиловый эфир 4,5,6,7-тетрагидро- $2 H$-изоиндол-1-карбоновой кислоты получали, как указано в ${ }^{[7]}$.

Спектры ЯМР ${ }^{1} \mathrm{H}$ и ${ }^{13} \mathrm{C}$ регистрировали на спектрометре Bruker Avance 400 на частотах 400 МГц для ядер ${ }^{~} \mathrm{H}$ и $100 \mathrm{MГц}$ для ядер ${ }^{13} \mathrm{C}$. Химические сдвиги измеряли с точностью до 0.01 м.Д., а КССВ с точностью до 0.1 Гц.

Масс-спектры с лазерной десорбционной ионизацией (LDI-TOF) регистрировали на приборе Bruker Daltonics Autoflex II при облучении азотным лазером на частоте 337 нм и ускоряющем напряжении 19 кВ. Масс-спектры с ионизацией электрораспылением (ESI-MS) и фотоионизацией были получены на приборе Agilent 1100 Series LC/MSD Tramp SL, спектры с фотоионизацией записывали, испаряя вещества из растворов в $\mathrm{CH}_{2} \mathrm{Cl}_{2}$ с добавлением толуола и $\mathrm{CH}_{3} \mathrm{CN}$. Теоретический расчет распределения интенсивности изотопных пиков проводился при помощи программы IsotopeViewer Version 1.0.

Оптическая спектроскопия. Электронные спектры поглощения были получены на спектрофотометре Agilent-8453, рабочий диапазон 190-1100 нм. Управление спектрофотометром, сбор данных и их простейшую математическую обработку проводили с помощью программы UV-Visible Chem.Station Rev. A.10.01. Спектры фосфоресценции регистрировали на спектрофлюориметре Элюмин-2М в 2-метилтетрагидрофуране при 77 К. Измерения проводили при ортогональнальном расположении детектора (ФЭУ-39А). Ширина спектральной щели составляла 10 нм.

Элементный анализ был выполнен в лаборатории микроанализа химического факультета МГУ им. М. В. Ломоносова.
Температуры плавления измеряли на приборе Mel-TempII и не корректировали.

Хроматография. Контроль с помощью ТСХ осуществляли напластинах DC-Alufolien Kieselgel $60 \mathrm{~F}_{254}$ (Merck). Колоночную хроматографию проводили на силикагеле Kieselgel 600.063 0.200 мм (Merck).

Фенил-бис(этоксикарбонил-4,5, 6,7-тетрагидро-2Hизоиндолил)метан (3). В 50 мл $\mathrm{CH}_{2} \mathrm{Cl}_{2}$ растворяли 1 г (5.18 ммоль) этилового эфира 4,5,6,7-тетрагидроизоиндол-2H-карбоновой кислоты $1,0.26$ мл (2.59 ммоль) свежеперегнанного бензальдегида и 0.108 г (0.39 ммоль) хлорида тетрабутиламмония, продували аргоном при перемешивании в течение 30 мин, после чего добавляли 0.066 мл (0.52 ммоль) эфирата трехфтористого бора. Перемешивали в атмосфере аргона 6 часов до полного исчезновения бензальдегида в реакционной смеси согласно данным ТCX, после чего промывали реакционную смесь $10 \%$ водным раствором $\mathrm{Na}_{2} \mathrm{CO}_{3}$, водой и насыщенным раствором $\mathrm{NaCl}$, высушивали над $\mathrm{Na}_{2} \mathrm{SO}_{4}$. Перекристаллизовывали продукт из гексана, получили 0.91 г (1.9 ммоль, 74\%) белого кристаллического вещества с $\mathrm{T}_{\text {пл }}=158-159{ }^{\circ} \mathrm{C}$. Найдено, \%: С 73.09, Н 7.02, N 5.41. $\mathrm{C}_{29} \mathrm{H}_{34} \mathrm{~N}_{2} \mathrm{O}_{4}$. Вычислено, \%: С 73.39, Н 7.22, N 5.90. $\mathrm{m} / \mathrm{z}$ (LDI-TOF) (\%) 473.09 (100) [(M-H) $\left.{ }^{+}\right], 497.06$ $(16 \%)\left[(\mathrm{M}+\mathrm{Na})^{+}\right], 513.00(5 \%)\left[(\mathrm{M}+\mathrm{K})^{+}\right] .{ }^{1} \mathrm{H}$ ЯMP $\left(\mathrm{CDCl}_{3}, 298 \mathrm{~K}\right)$

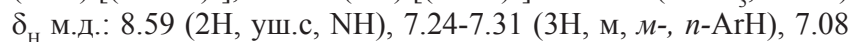
$(2 \mathrm{H}, \mathrm{м}, o-\mathrm{ArH}), 5.41(1 \mathrm{H}, \mathrm{c}$, мезо-CH), $4.19(4 \mathrm{H}, \mathrm{\kappa}, J=7.1$ Гц, $\left.-\mathrm{OCH}_{2} \mathrm{CH}_{3}\right), 2.77\left(4 \mathrm{H}, \mathrm{м}, \mathrm{H}-4\right.$ или Н-7(cyclo- $\left.\left.\mathrm{C}_{6}\right)\right), 2.17(4 \mathrm{H}, \mathrm{m}$, H-7 или Н-4(cyclo- $\left.\left.\mathrm{C}_{6}\right)\right), 1.63-1.70$ (8H, м, H-5,6 (cyclo- $\left.\left.\mathrm{C}_{6}\right)\right), 1.27$ $\left(6 \mathrm{H}, \mathrm{T}, J=7.1\right.$ Гц, $\left.-\mathrm{OCH}_{2} \mathrm{CH}_{3}\right) .{ }^{13} \mathrm{C}$ ЯMР $\left(\mathrm{CDCl}_{3}, 298 \mathrm{~K}\right) \delta_{\text {с м.д.: }}$ $161.76,139.04,130.78,129.22,128.89,128.20,127.26,119.75$ $116.77,59.71,40.62,23.33,23.16,21.26,14.49$.

$\left(2^{\prime}, 3^{\prime}, 5^{\prime}, 6^{\prime}, 8^{\prime}, 9^{\prime}, 11^{\prime}, 12^{\prime}\right.$-Октагидро- $1^{\prime}, 4^{\prime}, 7^{\prime}, 10^{\prime}, 13^{\prime}$-бензопентаоксаииклопентадецин-15'-ил)-бис(этоксикарбонил4,5,6,7-тетрагидро-2Н-изоиндолил)метан (4) синтезировали по методике, аналогичной описанной выше для соединения $\mathbf{3}$, из 2,3,5,6,8,9,11,12-октагидро-1,4,7,10,13-бензопентаоксациклопентадецин-15-карбальдегида 2 (0.305 г, 1.03 ммоль), этилового эфира 4,5,6,7-тетрагидроизоиндол- $2 H$-карбоновой кислоты 1 (0.398 г, 2.06 ммоль), хлорида тетрабутиламмония (0.042 г, 0.15 ммоль) и $\mathrm{BF}_{3} \cdot \mathrm{Et}_{2} \mathrm{O}$ (0.027 мл, 0.21 ммоль) в 25 мл $\mathrm{CH}_{2} \mathrm{Cl}_{2}$. После очистки методом колоночной хроматографии (силикагель, этилацетат) было получено 0.472 г (0.7139 ммоль, $69 \%$ ) светло-оранжевого твердого вещества с $\mathrm{T}_{\text {пл. }}=118-119{ }^{\circ} \mathrm{C}$. Найдено, \%: С 66.61, Н 7.15, N 4.10. $\mathrm{C}_{37} \mathrm{H}_{48} \mathrm{~N}_{2} \mathrm{O}_{9}$. Вычислено, \%: C 66.85, H 7.28, N 4.21. m/z (LDI-TOF) (\%) 663.14 (100) $\left[(\mathrm{M}-\mathrm{H})^{+}\right], 687.13(52 \%)\left[(\mathrm{M}+\mathrm{Na})^{+}\right] .{ }^{1} \mathrm{H}$ ЯMP $\left(\mathrm{CDCl}_{3}, 298 \mathrm{~K}\right) \delta_{\mathrm{H}}$ м.д.: 8.32 (2H, уш.с, $\mathrm{NH}), 6.79$ (1Н, д, $J=8.8$ Гц, Н-17 ArH), 6.60 (2H, м, H-14,16 ArH), 5.28 (1H, с, мезо-CH), 4.23 (4H, к, $J=7.1$ Гц, $\left.-\mathrm{OCH}_{2} \mathrm{CH}_{3}\right), 4.11$ (2H, м, H-2'), 4.03 (2H, м, H-12'), $3.90(2 \mathrm{H}$, м, H-3'), 3.86 (2H, м, H-11'), 3.74 (8Н, м, H-5 ', 6', ', ', '), 2.77 (4H, м, Н-4 или Н-7(cyclo- $\left.\mathrm{C}_{6}\right)$ ), 2.13 (4Н, м, Н-7 или Н-4(cyclo- $\left.\mathrm{C}_{6}\right)$ ), $1.66\left(8 \mathrm{H}, \mathrm{м}, \mathrm{H}-5,6\right.$ (cyclo- $\left.\left.\mathrm{C}_{6}\right)\right), 1.30\left(6 \mathrm{H}, \mathrm{T}, J=7.1\right.$ Гц, $\left.-\mathrm{OCH}_{2} \mathrm{CH}_{3}\right)$.

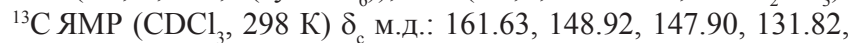
$130.65,129.38,121.15,119.62,116.54,113.82,113.76,70.60$, $70.18,69.13,68.62,68.54,59.71,40.51,23.79,23.28,23.08,21.21$, 14.52 .

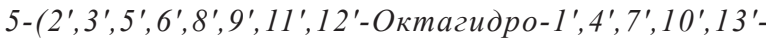
бензопентаоксациклопентадецин-15'-ил)-10,15,20-трифенилтетрациклогексенопорфирин (8).

Onblm 1. 0.202 г (0.43 ммоль) дипиррометана 3 и 0.087 г (1.54 ммоль) КОН растворяли при нагревании в 2 мл моноэтиленгликоля в атмосфере аргона. Кипятили реакционную смесь при перемешивании в течение 8 часов, после чего охлаждали до $0{ }^{\circ} \mathrm{C}$ и оставляли на ночь в морозильной камере. На следующий день добавляли 15 мл $\mathrm{CH}_{2} \mathrm{Cl}_{2}$, промывали органическую фазу ледяной водой и насыщенным раствором $\mathrm{NaCl}$, высушивали над $\mathrm{Na}_{2} \mathrm{SO}_{4}$. Фильтровали раствор через фильтр с силикагелем, добавляли $\mathrm{CH}_{2} \mathrm{Cl}_{2}$ до объема 200 мл. 
К полученному раствору в атмосфере аргона добавляли раствор 0.126 г (0.426 ммоль) $\mathcal{M}$-формилбензокраун-эфира 2 в 20 мл $\mathrm{CH}_{2} \mathrm{Cl}_{2}$. Перемешивали реакционную смесь в течение 40 мин, после чего добавляли 0.022 г (0.129 ммоль) $\mathrm{TsOH}$. Перемешивали получившийся раствор в течение 4 часов, предварительно защитив его от света, затем добавляли 0.194 г (0.853 ммоль) DDQ. Продолжали перемешивание в течение 12 ч. После окончания перемешивания промывали реакционную смесь $10 \%$ водным раствором $\mathrm{NaHSO}_{3}, 10 \%$ водным раствором $\mathrm{Na}_{2} \mathrm{CO}_{3}, 5 \%$ водным раствором $\mathrm{HCl}$ и насыщенным раствором $\mathrm{NaCl}$, высушивали органическую фазу над $\mathrm{Na}_{2} \mathrm{SO}_{4}$.

Согласно данным LDI-TOF, продукты реакции представляли собой порфирины со всеми возможными сочетаниями фенильных и бензокраун-эфирных заместителей (см. Схема 3). При помощи колоночной хроматографии (силикагель, ТГФ/гексан 1:1, с постепенным добавлением метанола до 20\%) удалось выделить 5 мг тетрафенилтетрациклогексенопорфирина 7 и 3 мг моно-мезо-бензокраун-замещенного порфирина $\mathbf{8}$, содержащего значительное количество примесей согласно ТСХ. Остальные вещества не удалось выделить в индивидуальном виде - выделялись их смеси в различных соотношениях. Ввиду значительной трудоемкости разделения и незначительного содержания порфиринов дальнейшая очистка выделенных фракций не проводилась.

ЭСП $\left(\mathrm{CH}_{2} \mathrm{Cl}_{2}\right) \lambda_{\text {макс }}$ нм (отн. инт.): 468 (9.8), 673 (1). $\mathrm{m} / \mathrm{z}$ (LDI-TOF): вычислено 1020.52, найдено 1021.21, изотопное распределение пиков полностью совпадает с расчетным.

Onblm 2. 0.197 г (0.296 ммоль) дипиррометана 4 и 0.060 г (1.07 ммоль) КОН растворяли при нагревании в 4 мл моноэтиленгликоля в атмосфере аргона. Кипятили реакционную смесь при перемешивании в течение 9.5 ч, после чего охлаждали до $0^{\circ} \mathrm{C}$, добавляли 15 мл $\mathrm{CH}_{2} \mathrm{Cl}_{2}$, промывали органическую фазу ледяной водой и насыщенным раствором $\mathrm{NaCl}$, высушивали над $\mathrm{Na}_{2} \mathrm{SO}_{4}$. Фильтровали раствор через фильтр с силикагелем, добавляли $\mathrm{CH}_{2} \mathrm{Cl}_{2}$ до объема 150 мл. К полученному раствору в атмосфере аргона добавляли раствор 0.126 г (0.031 ммоль) бензальдегида в 20 мл $\mathrm{CH}_{2} \mathrm{Cl}_{2}$. Перемешивали реакционную смесь в течение 40 мин, после чего добавляли 0.016 г (0.09 ммоль) ТsOH. Перемешивали получившийся раствор, предварительно защитив его от света, в течение 4 часов, затем добавляли 0.068 г (0.853 ммоль) DDQ. Продолжали перемешивание в течение 12 ч. После окончания перемешивания промывали реакционную смесь 10\% водным раствором $\mathrm{NaHSO}_{3}, 10 \%$ водным раствором $\mathrm{Na}_{2} \mathrm{CO}_{3}, 5 \%$ водным раствором $\mathrm{HCl}$ и насыщенным раствором $\mathrm{NaCl}$, высушивали органическую фазу над $\mathrm{Na}_{2} \mathrm{SO}_{4}$.

Согласно данным LDI-TOF, в полученном продукте содержались следы некраунированного порфирина 7 и не содержалось следов краун-порфиринов.

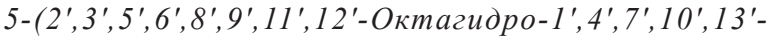
бензопентаоксаииклопента-децин-15'-ил)-10,15,20-трифенилтетрациклогексенопорфирин палладия (8-Pd).

a) 0.5 г (1.05 ммоль) дипиррометана 3 и 0.21 г (3.8 ммоль) КОН в атмосфере аргона растворяли в 7 мл моноэтиленгликоля. Кипятили реакционную смесь в течение 8.5 часов, образовавшийся темно-коричневый раствор оставляли в инертной атмосфере на ночь в морозильной камере. На следующий день добавляли к раствору $\mathrm{CH}_{2} \mathrm{Cl}_{2}$, промывали ледяной водой, насыщенным раствором $\mathrm{NaCl}$. Высушивали органическую фазу над $\mathrm{Na}_{2} \mathrm{SO}_{4}$. Полученный раствор пропускали через короткую хроматографическую колонку (силикагель, $\mathrm{CH}_{2} \mathrm{Cl}_{2}$ ), получив оранжево-красный раствор. К 200 мл полученного раствора в атмосфере аргона добавляли раствор 0.056 г (0.53 ммоль) бензальдегида и 0.156 г (0.53 ммоль) формилбензокраун-эфира 2 в 50 мл $\mathrm{CH}_{2} \mathrm{Cl}_{2}$. Защитив колбу от света, перемешивали раствор в течение 40 минут, после чего добавляли 0.055 г (0.32 ммоль) TsOH. Перемешивали реакционную смесь в течение 16 часов, затем добавляли 0.478 г DDQ (2.107 ммоль), растворенного в $\mathrm{CH}_{2} \mathrm{Cl}_{2}$, и перемешивали при комнатной температуре еще 15 часов. После окончания перемешивания промывали реакционную смесь $10 \%$ водным раствором $\mathrm{NaHSO}_{3}, 10 \%$ водным раствором $\mathrm{Na}_{2} \mathrm{CO}_{3}, 5 \%$ водным раствором $\mathrm{HCl}$ и насыщенным раствором $\mathrm{NaCl}$, высушивали органическую фазу над $\mathrm{Na}_{2} \mathrm{SO}_{4}$. Растворитель упаривали, получив твердое вещество черно-зеленого цвета. Согласно данным масс-спектрометрии с фотоионизацией, в полученном продукте кроме низкомолекулярных примесей содержались тетрафенилтетрабензопорфирин 7 и моно-мезо-бензокраунзамещенный порфирин 8.

б) Полученную смесь порфиринов (0.0556 г) растворяли в 80 мл смеси ТГФ: $\mathrm{CH}_{3} \mathrm{CN}(1: 1)$, добавляли 0.2 г (2 ммоль) $\mathrm{NEt}_{3}, 0.04$ г (0.2 ммоль) $\mathrm{PdCl}_{2}$. Кипятили реакционную смесь в течение 40 мин, после чего добавляли еще 0.02 г (0.1 ммоль) $\mathrm{PdCl}_{2}$ и кипятили еще 1.5 часа. После окончания кипячения фильтровали реакционную смесь через фильтр с силикагелем, упаривали растворитель. Полученное темно-красное вещество разделяли методом колоночной хроматографии (силикагель, толуол/ТГФ 3:1). Собирали две красные фракции. Согласно данным LDI-TOF, первая фракция являлась тетрафенилтетрациклогексенопорфирином 7-Pd. Упаривали растворитель, содержащий вторую красную фракцию, получили 0.0095 г (0.0084 ммоль, $16 \%)$ твердого красного вещества, являющегося целевым соединением 8-Pd.

ЭСП $\left(\mathrm{CHCl}_{3}\right) \lambda_{\text {макс }}$ нм (отн. инт.): 426 (14.1), 537 (1.43), 572 (1). ' $\mathrm{H}$ ЯМР ([D $]$ ацетон, $298 \mathrm{~K}) \delta_{\mathrm{H}}$ м.д.: $8.06(6 \mathrm{H}, \mathrm{м}, o-\mathrm{PhH})$, $7.63\left(11 \mathrm{H}, \mathrm{м}, \mathcal{M -}^{-}, n-\mathrm{PhH}, \mathrm{H}-14^{\prime}, \mathrm{H}-16^{\prime}\right), 7.12(1 \mathrm{H}$, д, $J=8.6$ Гц, H-17'), 4.37 (2H, м, H-2') ${ }^{*}, 4.23$ (2H, м, H-12'), 4.06 (2H, м, Н-3'), 3.95 (2Н, м, Н-11'), 3.87 (4Н, м, Н-5',9' или 6', ', ), 3.83 (4Н, уш.с., Н-6',8' или 5',9'), 2.39 (4Н, уш.с., Н-2 ${ }^{4}, 7^{1}$ (cyclo$\left.\left.\mathrm{C}_{6}\right)\right), 2.27$ (12H, уш.с., H-2 ${ }^{1}, 7^{1}, 12^{1}, 12^{4}, 17^{1}, 17^{4}$ (cyclo- $\left.\mathrm{C}_{6}\right)$ ), 1.44 (16H, м, H- $2^{2}, 2^{3}, 7^{2}, 7^{3}, 12^{2}, 12^{3}, 17^{2}, 17^{3}$ (cyclo-C $)$ ). m/z (LDI-TOF): вычислено 1124.40 , найдено 1124.69 , изотопное распределение пиков представляет собой наложение спектров $[\mathrm{M}]$ и $[\mathrm{M}+\mathrm{H}]$.

5-(2', 3', 5', 6', 8', 9', 11', 12'-Октагидро- $1^{\prime}, 4^{\prime}, 7^{\prime}, 10^{\prime}, 13^{\prime}$ бензопентаоксаииклопентадецин-15'-ил)-10,15,20трифенилтетрабензопорфирин палладия (II) (12-Pd).

0.022 г (0.02 ммоль) порфирина 8-Pd растворяли в 50 мл THF, добавляли 0.073 г (0.32 ммоль) DDQ. Кипятили раствор в течение 40 минут. После окончания кипячения упаривали $2 / 3$ объема растворителя, добавляли $\mathrm{CH}_{2} \mathrm{Cl}_{2}$, промывали органическую фазу $10 \%$ раствором $\mathrm{NaHSO}_{3}$, водой и насыщенным раствором $\mathrm{NaCl}$, высушивали над $\mathrm{Na}_{2} \mathrm{SO}_{4}$. Упаривали растворитель, образовавшееся твердое темно-зеленое вещество очищали при помощи колоночной хроматографии (силикагель, толуол/EtOH 10:1), собирая первую зеленую фракцию. Упаривали растворитель, получили 0.0154 г (0.014 ммоль, $71 \%)$ фиолетово-зеленого вещества. ЭСП

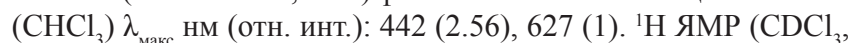
$298 \mathrm{~K}) \delta_{\mathrm{H}}$ м.д.: 8.24 (6H, м, o-PhH), 7.99 (9H, м, $\left.M-, n-\mathrm{PhH}\right), 7.87$ $\left(1 \mathrm{H}\right.$, д, $J=2.1$ Гц, H-14'), $7.72\left(1 \mathrm{H}\right.$, дд, $J_{1}=8.1$ Гц, $J_{2}=2.1$ Гц, Н-16'), 7.52 (1Н, д, J = 8.1 Гц, Н-17'), 7.34 (м, $\left.\mathrm{H}_{\text {benzo }}\right), 7.24$ (м, $\mathrm{H}_{\text {ben }}$ zо $), 7.14$ (м, $\left.\mathrm{H}_{\text {benzo }}\right)\left(\right.$ все $\left.\mathrm{H}_{\text {benzo }}-16 \mathrm{H}\right) 4.51$ (2H, м, H-2'), 4.24 (2H, м, H-12'), 4.09 (2H, м, H-3'), 3.82 (10H, м, H-5', 6', $\left.8^{\prime}, 9^{\prime}, 11^{\prime}\right) . ~ m / z$ (LDI-TOF): вычислено 1108.27, найдено 1108.36, изотопное распределение пиков полностью совпадает с расчетным.

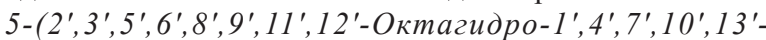
бензопентаоксациклопента-децин-15'-ил)-10,15,20-трифенилтетрациклогексенопорфирин меди (II) $(\mathbf{8}-\mathrm{Cu})$.

0.047 г смеси порфиринов, полученной в части (a) синтеза тетрафенилтетрациклогексенопорфирина 8-Pd, растворяли в 50 мл смеси $\mathrm{CHCl}_{3}-\mathrm{CH}_{3} \mathrm{OH}$ (9:1), добавляли 0.566 г (2.83 ммоль)

\footnotetext{
* Нумерация атомов краун-эфирного фрагмента аналогична приведённой для соед. 4.
} 
$\mathrm{Cu}(\mathrm{OAc})_{2} \cdot \mathrm{H}_{2} \mathrm{O}$. Реакционная смесь окрашивалась в чернокоричневый цвет. Оставляли перемешиваться при комнатной температуре. Через 1.5 часа после начала перемешивания добавляли 1 мл (0.716 г, 7.08 ммоль) триэтиламина, при этом не наблюдалось изменения цвета раствора. Перемешивание при комнатной температуре вели еще в течение 1 часа. Промывали реакционную смесь по несколько раз $10 \%$ водным раствором уксусной кислоты и $10 \%$ водным раствором $\mathrm{Na}_{2} \mathrm{CO}_{3}$, водой и насыщенным раствором $\mathrm{NaCl}$. Высушивали над $\mathrm{Na}_{2} \mathrm{SO}_{4}$. Упаривали растворитель, полученное твердое вещество черно-коричневого цвета разделяли методом колоночной хроматографии (силикагель, толуол/ТГФ $3: 1$, затем постепенно повышали содержание ТГФ в элюенте до 100\%). Собирали три красно-коричневые фракции. Согласно данным LDI-TOF, вторая фракция являлась целевым соединением - тетрафенилтетрациклогексенопорфирином 8-Сu. Упаривали растворитель, получили 0.0097 г (0.00896 ммоль, 18\%) твердого красного вещества. ЭСП $\left(\mathrm{CH}_{2} \mathrm{Cl}_{2}\right) \lambda_{\text {макс }}$ нм (отн. инт.): 425 (9.4), 557 (1). $\mathrm{m} / z$ (LDI-TOF): вычислено 1081.43, найдено 1081.25, изотопное распределение пиков полностью совпадает с расчетным.

\section{Результаты и обсуждение}

\section{Синтез}

Существует три основных методики синтеза мезо-замещённых порфиринов - Адлера-Лонго ${ }^{[22]}$ и две разновидности метода Линдси. ${ }^{[23]}$ Мы исследовали возможность применения этих методик к низкотемпературному синтезу мезо-краунированных тетрациклогексено- и тетрабензопорфиринов.

Попытки взаимодействия 4,5,6,7-тетрагидро$2 H$-изоиндола с мета-формилбензо-15-крауном-5 в условиях реакций Адлера-Лонго и Линдси не привели к образованию продукта, который можно было бы выделить в виде индивидуального вещества.

Поэтому было решено использовать разновидность метода Линдси - конденсацию альдегидов с производными дипиррометанов в кислой среде с последующим окислением. Такая синтетическая последовательность приводила ранее к успеху в случае порфиринов, в которых одинаковые заместители сгруппированы попарно в противоположных мезо-положениях (Схема 1,a), и, в частности, при синтезе диарилзамещенных тетрабензопорфиринов. ${ }^{[6]}$ Данная методика позволяет также проводить синтез порфиринов с одним мезо-заместителем, отличающимся от трех остальных (Схема 1,b).

В рамках данного подхода возможны два варианта синтеза мезо-бензокраун-тетрациклогексенопорфиринов: через конденсацию соединения 5 (Схемы 2 и 3) с м-формилбензокраун-эфиром или через конденсацию соединения 6 с бензальдегидом.
Для синтеза соединений 3 и $\mathbf{4}$ мы использовали литературные методики, ${ }^{[6]}$ взяв в качестве катализатора эфират трехфтористого бора.

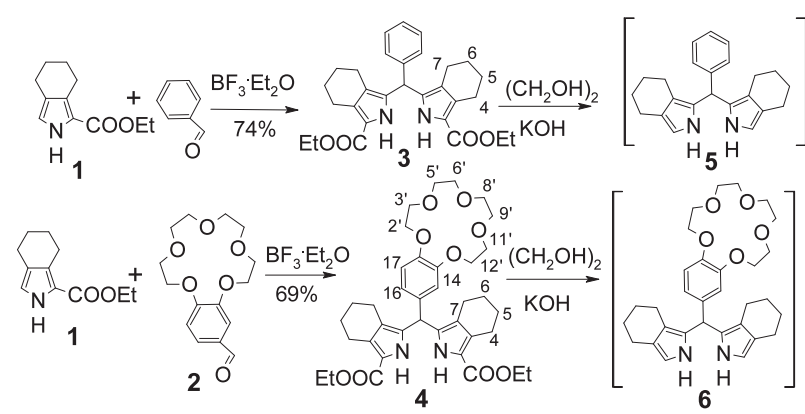

Схема 2. Синтез дипиррометанов 3-6.

Полученные дипиррометаны 3-4 были подвергнуты декарбоксилированию с образованием соединений 5-6. Последние неустойчивы, поэтому реакцию декарбоксилирования проводили в ходе синтеза порфиринов, непосредственно перед конденсацией.

При конденсации дипиррометана 5 с M-формилбензокраун-эфиром 2 (соотношение реагентов $1: 1$, катализатор $\mathrm{TsOH}$, окислитель DDQ) вместо ожидаемого 5,15-дифенил-10,20-дибензокраунтетрациклогексенопорфирина 9, согласно данным LDI-TOF, в реакционной смеси присутствовали тетрациклогексенопорфирины со всеми возможными комбинациями фенильных и бензокраун-эфирных заместителей в мезо-положениях (Схема 3, Рисунок 1).

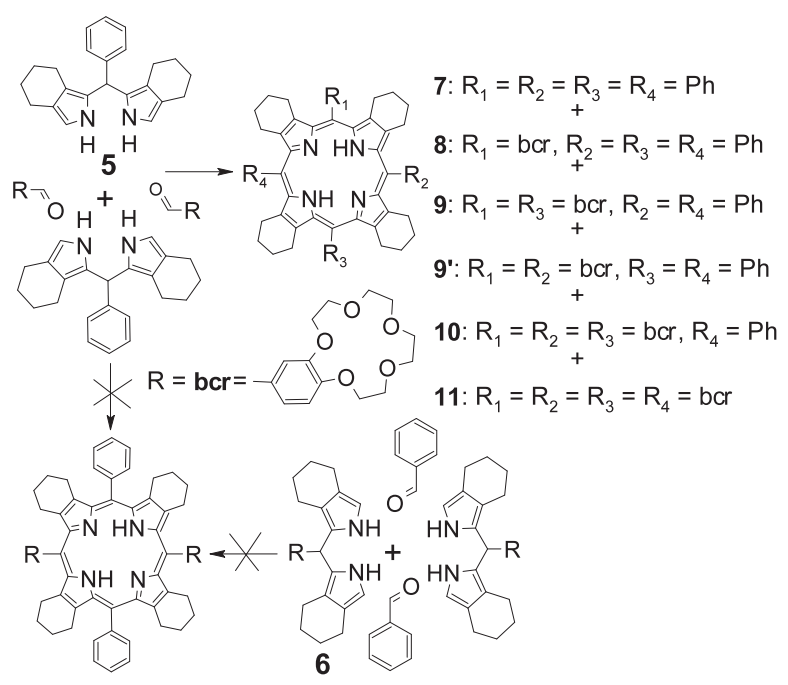

Схема 3. Синтез порфиринов 7-11.

При помощи колоночной хроматографии из реакционной смеси были выделены фракции, содержащие
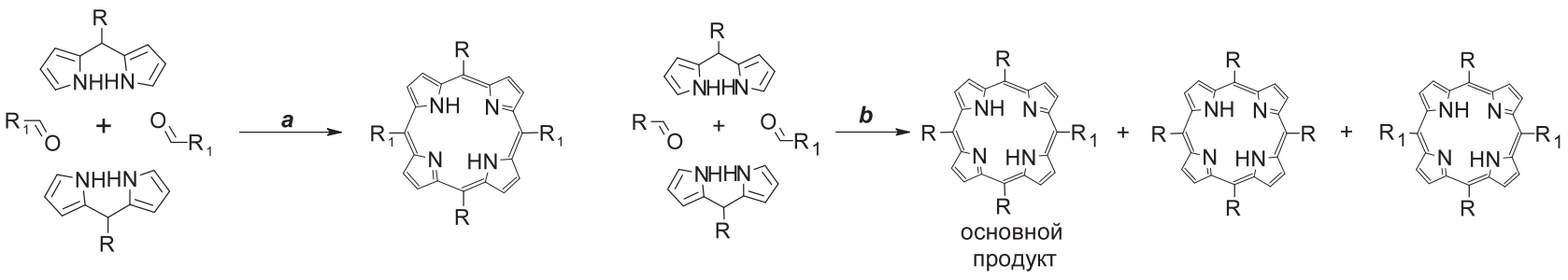

Схема 1. Получение порфиринов методом Линдси на основе дипиррометана. 


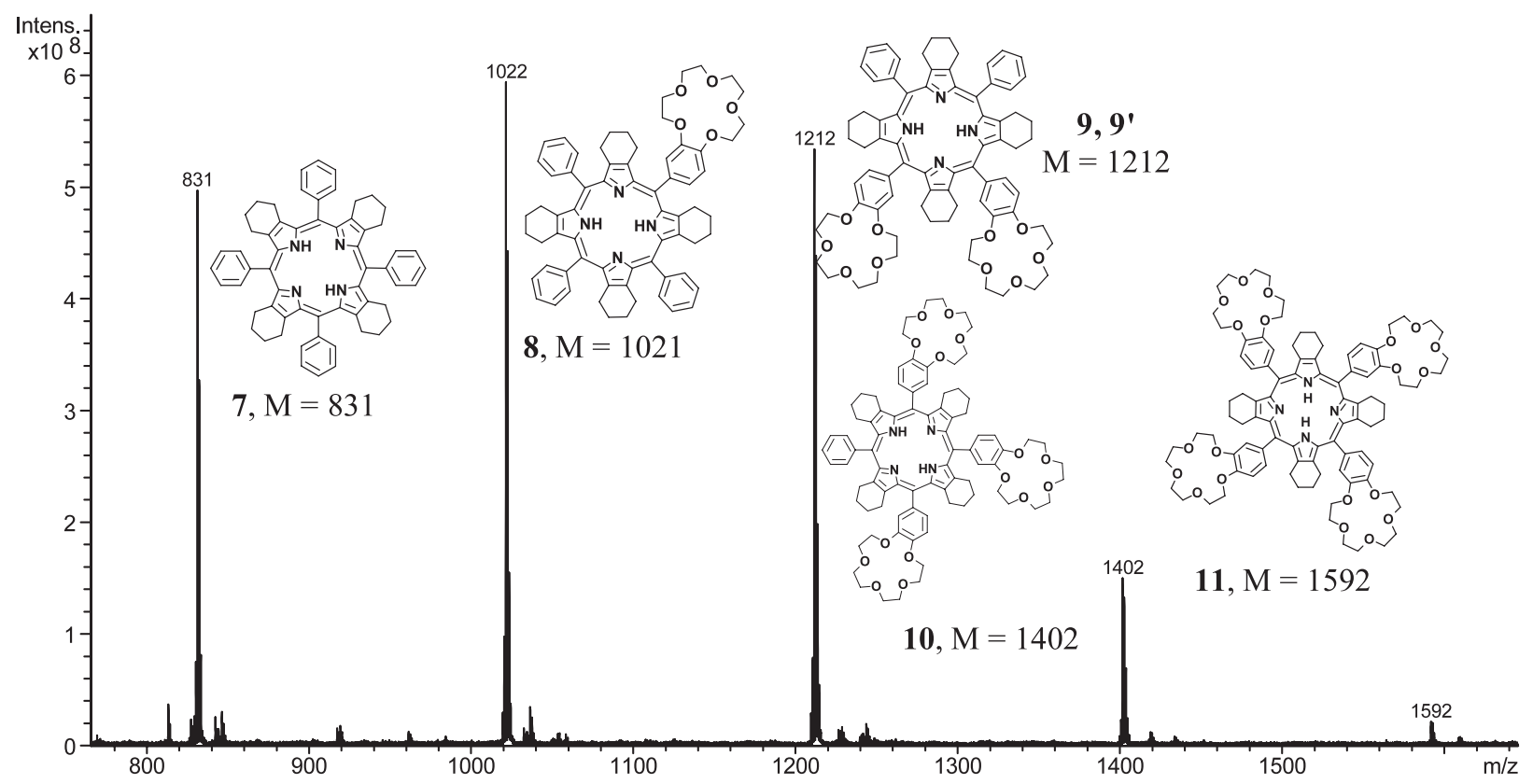

Рисунок 1. Спектр LDI-TOF продуктов конденсации дипиррометана 5 с м-формилбензокраун-эфиром 2.

тетрафенилтетрациклогексенопорфирин 7 и монобензокраун-тетрациклогексенопорфирин 8. Остальные вещества не удалось выделить в индивидуальном виде - как правило, выделялись их смеси в различных соотношениях.

Образование смеси порфиринов с различными заместителями в мезо-положениях объясняется процессом перетасовки заместителей («скрэмблинга») обмена заместителями между различными молекулами - линейными предшественниками порфириногена.

Протекание «скрэмблинга» зависит от большого количества параметров, и подбор условий, его минимизирующих, является трудоёмкой задачей. ${ }^{[24-26]}$ Мы предположили, что, вследствие статистического характера распределения заместителей, образование порфиринов с двумя и более краун-эфирными фрагментами будет подавлено в случае использования смеси бензальдегида и формилбензокраун-эфира 2. Облегчению хроматографического разделения, по нашему мнению, могло бы способствовать также введение в него смеси металлированных порфиринов, поскольку в последних отсутствовали бы NH- и N: фрагменты центральной части молекулы порфиринов, взаимодействующие с сорбентом.

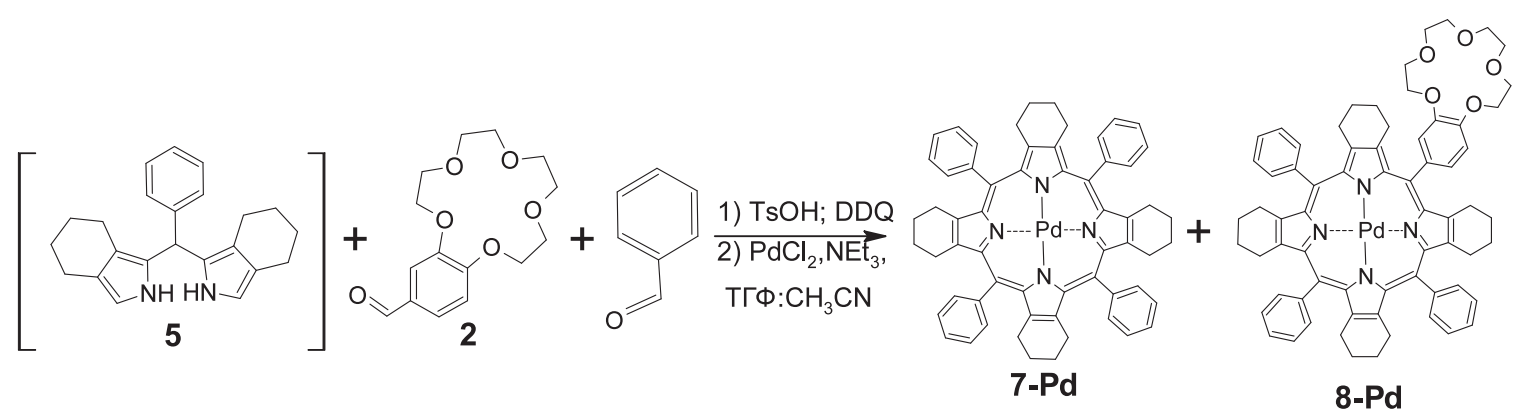

Схема 4. Синтез порфиринов палладия 7-Pd и 8-Pd.
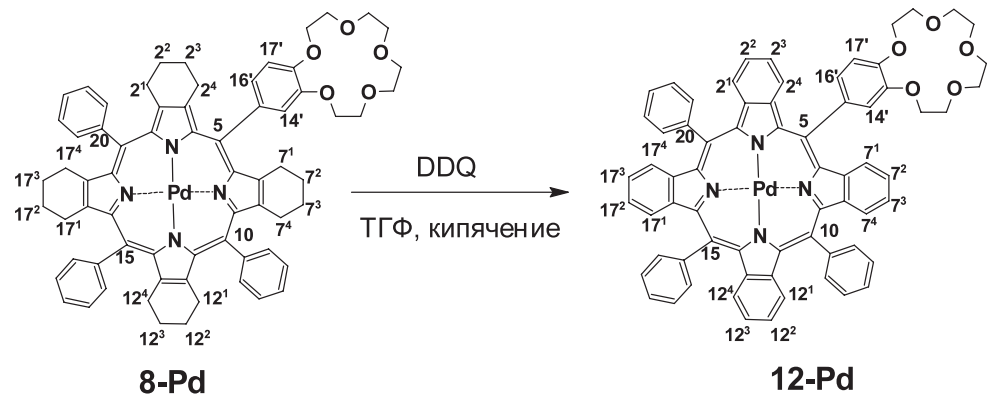

Схема 5. Синтез тетрабензопорфирина 12-Pd (нумерация атомов проведена согласно номенклатуре IUPAC). 

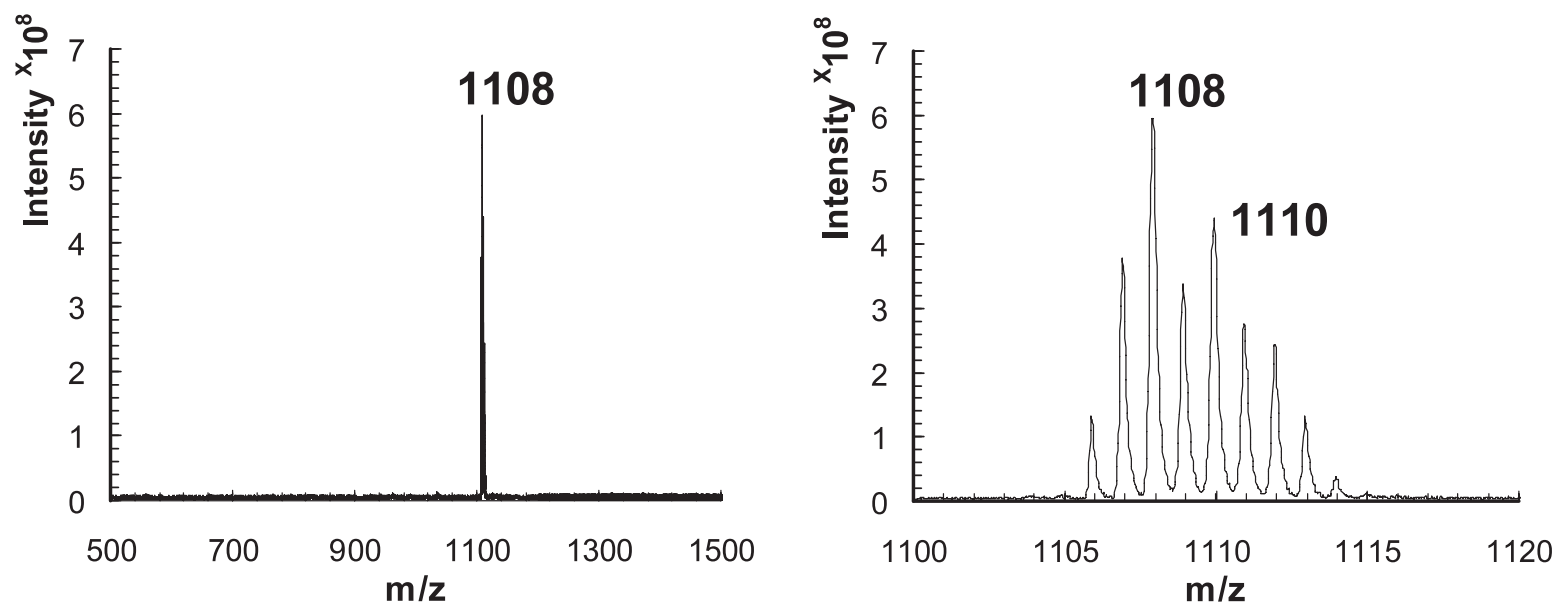

Рисунок 2. Масс-спектр LDI-TOF порфирина 12-Pd.

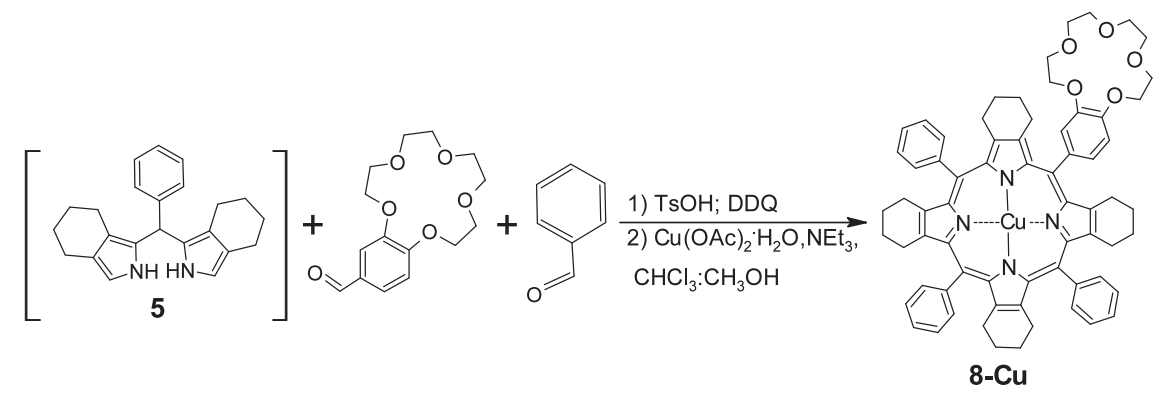

Схема 6. Синтез порфирина 8-Cu.

Действительно, введение в конденсацию с дипиррометаном $\mathbf{5}$ смеси бензальдегида и формилбензокраун-эфира в соотношении 1:1 привело к образованию смеси, содержащей тетрафенилтетрациклогексенопорфирин 7 и моно-бензокраунтетрациклогексанопорфирин 8 согласно данным масс-спектрометрии с электрораспылением-фотоионизацией. Металлирование получившейся смеси привело к образованию соединений 7-Pd и 8-Pd, которые были успешно выделены при помощи колоночной хроматографии (с суммарным выходом последнего 16\%) (Схема 4).

Ароматизация 8-Pd при помощи DDQ привела к образованию моно-бензокраун-тетрабензопорфирина палладия 12-Pd (Схема 5, Рисунок 2).

Та же смесь порфиринов, полученная при конденсации дипиррометана 5 и смеси бензальдегида с формилбензокраун-эфиром 2, была подвергнута металлированию ацетатом меди. Как и в случае комплекса с палладием, методом колоночной хроматографии удалось выделить моно-бензокраунтетрациклогексеноп орфирин меди 8-Сu с общим выходом 18\% (Схема 6).

Спектры ПМР всех полученных соединений отвечают синтезированным структурам. Так, во всех соединениях, содержащих бензокраун-эфирный фрагмент, сигналы метиленовых групп краун-эфирного фрагмента располагаются в более сильном поле по мере увеличения расстояния от бензольного кольца. Различимы лишь сигналы тех протонов, которые находятся либо в непосредственной близости (Н-2',12'), либо соседние с ними (Н-3', 11'). Резонансы более отдалённых ядер ${ }^{1} \mathrm{H} \quad\left(\mathrm{H}^{\prime} 5^{\prime}, 6^{\prime}, 8^{\prime}, 9^{\prime}\right)$, как правило, либо сливаются в неразрешённый мультиплет, либо наблюдаются как синглет. Циклогексановые протоны 8-Pd суммарно дают интегральную интенсивность, согласующуюся с предполагаемой структурой. Интересно, что метиленовые группы, ближние к порфириновому ядру, наблюдаются в виде двух сигналов в соотношении 12 (2.27 м.д.) : 4 (2.39 м.д.). Вероятно, последний сигнал относится к метиленовым группам, соседним к «особенному» бензольному кольцу, аннелированному к краун-эфирному фрагменту. В спектре ПМР 12-Pd, аналогично, хорошо различимы сигналы мезо-фенильных колец и бензокраун-фенильного кольца, последние представляют собой АМХ систему, характерную для тризамещённого бензола. Спектр бензопротонов данного соединения распадается на более сложный набор сигналов, в котором видны изменённые мультиплеты АA'BB' бензо-колец, удалённых от краунэфирного заместителя, а также несколько мультиплетов, обусловленных неодинаковостью мезо-фенильных заместителей. Точное отнесение данных сигналов невозможно без дальнейших исследований, однако все они в результате дают интегральную интенсивность, соответствующую числу бензо-протонов.

Альтернативный подход к синтезу мезозамещенного порфирина 9, основанный на конденсации дипиррометана 6 с бензальдегидом (Схема 3), не дал желаемого результата. Масс-спектрометрия LDITOF показала присутствие в реакционной смеси некраунированного тетрафенилтетрациклогексенопор- 
фирина 7 и отсутствие краунсодержащих порфиринов. По-видимому, в этом случае преобладают побочные процессы: ацидолиз дипиррометана 6, в результате которого в смеси образуется тетрапиррометаны, не содержащие краун-эфирные фрагменты, а также образование полипирролов, которые не приводят к образованию порфириногенов.

\section{Оптические свойства}

Для всех синтезированных порфиринов были измерены электронные спектры поглощения в УФ и видимой областях (Рисунок 3, Таблица 1).
Сравнение полученных спектров с литературными данными $^{[5,27]}$ показало, что введение краун-эфирных фрагментов незначительно отражается на оптических свойствах рассматриваемых порфиринов (Таблица 1).

Как известно, тетрафенилтетрабензопорфирины палладия, в отличие от их предшественников, тетрациклогексенопорфиринов, обладают ярко выраженной способностью к фосфоресценции. ${ }^{[28]}$

Нами был снят спектр испускания впервые синтезированного краунированного тетрабензопорфирина палладия 12-Pd (Рисунок 4). Сравнение полученного спектра со спектром испускания некраунированного аналога $\mathrm{PdPh}_{4} \mathrm{TBP}$ показало, что

Таблица 1. Сравнение ЭСП синтезированных моно-мезо-замещенных краун-порфиринов и их некраунированных аналогов (растворитель $\left.\mathrm{CH}_{2} \mathrm{Cl}_{2}\right) \cdot{ }^{[5,27]}$

\begin{tabular}{|c|c|c|c|c|}
\hline № & Соединение & Полоса Сорэ $\lambda_{\text {max }}$, нм & $Q$ полоса $\lambda_{\max }$, нм & $\begin{array}{c}\text { Отношение интенсив- } \\
\text { ностей } A_{\text {сорэ }} / A_{Q}\end{array}$ \\
\hline \multirow[t]{2}{*}{1} & $\mathrm{H}_{2} \mathrm{Ph}_{4} \mathrm{TCHP}$ & 464 & 670 & 11.1 \\
\hline & $\mathrm{H}_{2}(\mathrm{Ph})_{3}(\mathrm{bcr}) \mathrm{TCHP}(\mathbf{8})$ & 468 & 673 & 9.8 \\
\hline \multirow[t]{2}{*}{2} & $\mathrm{CuPh}_{4} \mathrm{TCHP}$ & 424 & 557 & 10 \\
\hline & $\mathrm{Cu}(\mathrm{Ph})_{3}(\mathrm{bcr}) \mathrm{TCHP}(\mathbf{8}-\mathbf{C u})$ & 425 & 557 & 9.4 \\
\hline \multirow[t]{2}{*}{3} & $\mathrm{PdPh}_{4} \mathrm{TCHP}$ & 426 & 536 & 10.2 \\
\hline & $\mathrm{Pd}(\mathrm{Ph})_{3}(\mathrm{bcr}) \mathrm{TCHP}(\mathbf{8}-\mathbf{P d})$ & 426 & 537 & 9.9 \\
\hline \multirow[t]{2}{*}{4} & $\mathrm{PdPh}_{4} \mathrm{TBP}$ & 441 & 627 & 2.7 \\
\hline & $\mathrm{Pd}(\mathrm{Ph})_{3}(\mathrm{bcr}) \mathrm{TBP}(\mathbf{1 2}-\mathbf{P d})$ & 442 & 627 & 2.6 \\
\hline
\end{tabular}

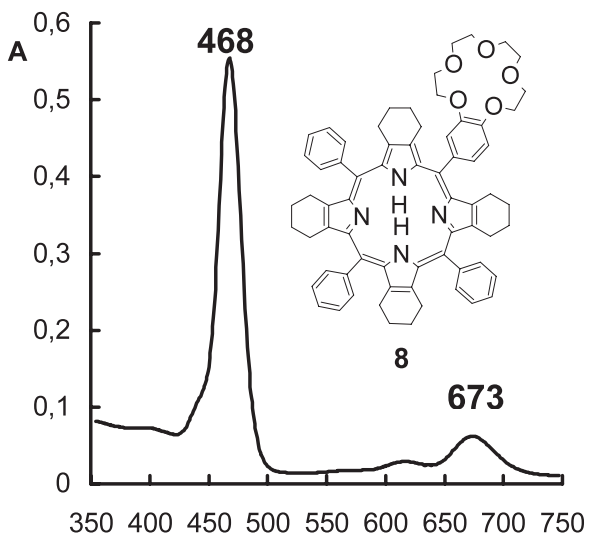

$\lambda$, нм

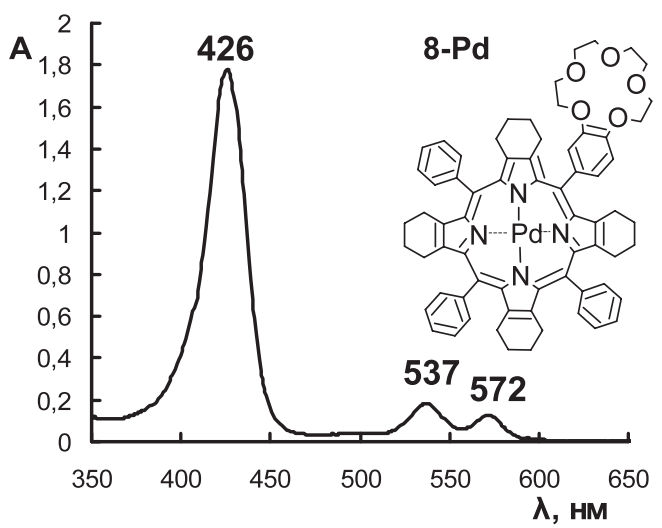

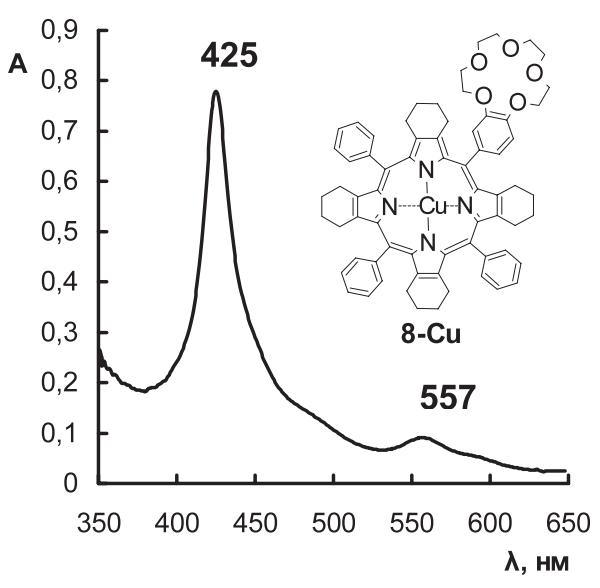

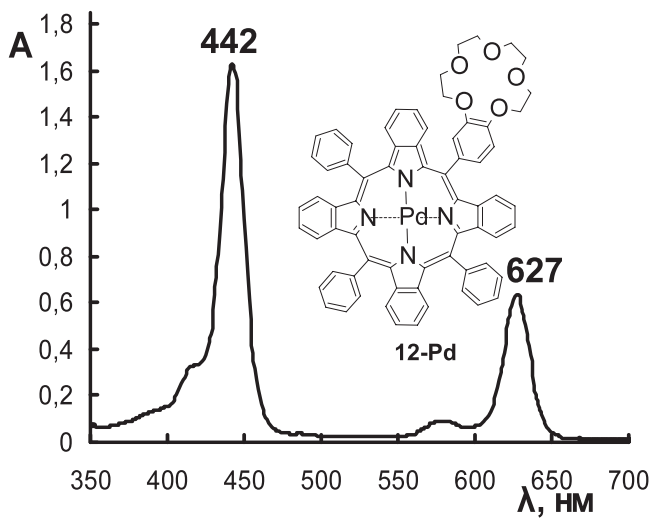

Рисунок 3. Электронные спектры поглощения синтезированных краун-порфиринов в $\mathrm{CH}_{2} \mathrm{Cl}_{2}$. 


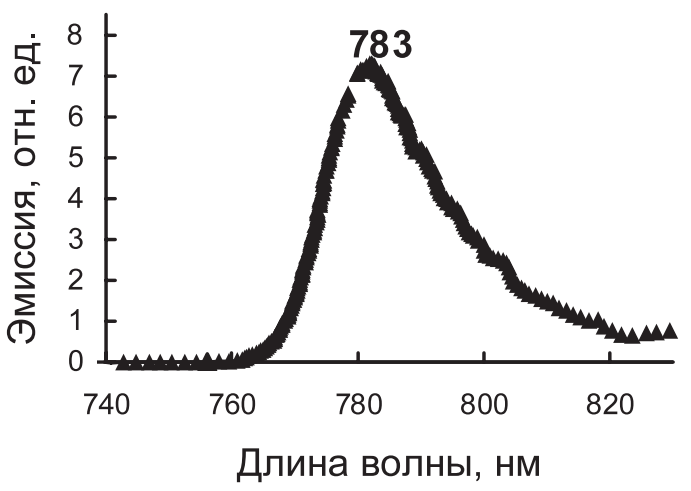

Рисунок 4. Спектр фосфоресценции краун-тетрабензопорфирина палладия 12-Pd в 2-метилтетрагидро-фуране $\left(\lambda_{\text {возб. }}=440 \mathrm{Hм}\right.$, ширина щели $10 \mathrm{Hм}, 77$ К).

введение в структуру порфирина краун-эфирного фрагмента никак не сказывается на положении максимума фосфоресценции.

\section{Выводы}

В данной работе впервые был проведен поиск условий образования порфиринового кольца при конденсации тетрагидроизоиндола и полученных из него дипиррометанов с формилбензокраун-эфиром или его смесью с бензальдегидом и найден способ получения моно-мезобензокраун-замещенных тетрациклогексено- и тетрабензопорфиринов исходя из фенил-бис(этоксикарбонил4,5,6,7-тетрагидро- $2 H$-изоиндолил)метана. Показано, что более высокие выходы тетрациклогексенопорфиринов палладия и меди достигаются при металлировании смеси порфиринов без предварительного разделения методом колоночной хроматографии. Получены спектры поглощения всех синтезированных порфиринов, а также спектр фосфоресценции краунсодержащего тетрабензопорфирина палладия. Установлено, что введение краун-эфирного фрагмента незначительно отражается на оптических свойствах исследуемых порфиринов по сравнению с их некраунированными аналогами. Впервые полученные бензокраунсодержащие тетрациклогексенои тетрабензопорфирины могут найти применение в качестве сенсоров на ионы металлов и органические молекулы. Предложенный подход для получения бензозамещенных тетрафенилтетрабензопорфиринов также может использоваться для синтеза тетрабензопорфиринов с широким спектром заместителей.

Благодарности. Работа выполнена при поддержке РФФИ (грант 09-03-00550а).

\section{Список литературы}

\section{References}

1. Bonnett R. Chem. Soc. Rev. 1995, 24, 19-33.

2. Brunel M., Chaput F., Vinogradov S.A., Campagne B., Canva M., Boilot J.P., Brun A. Chem. Phys. 1997, 218, 301-307.

3. Vinogradov S.A., Wilson D.F. Adv. Exp. Med. Biol. 1997, 411, 597-603.

4. Rietveld I.B., Kim E., Vinogradov S.A. Tetrahedron 2003, 59, 3821-3831.

5. Finikova O.S., Chernov S.Y., Cheprakov A.V., Filatov M.A., Vinogradov S.A., Beletskaya I.P. Doklady Akademii Nauk 2003, 391, 781-783 (in Russ.).

6. Filatov M.A., Lebedev A.Y., Vinogradov S.A., Cheprakov A.V. J. Org. Chem. 2008, 73, 4175-4185.

7. Finikova O.S., Cheprakov A.V., Carroll P.J., Vinogradov S.A. J. Org. Chem. 2003, 68, 7517-7520.

8. Ono N. Heterocycles 2008, 75, 243-284 and references cited therein.

9. Kopranenkov V.N., Vorotnikov A.M., Luk'yanets E.A. Zh. Obshch. Khim. 1979, 49, 2783-2784 (in Russ.).

10. Kopranenkov V. N., Dashkevich S. N., Luk'yanets E. A. Zh. Obshch. Khim. 1981, 51, 2513-2517 (in Russ.).

11. Galanin N.E., Kudrik E.V., Shaposhnikov G.P. Russ. J. Gen. Chem. 2000, 70, 1292-1295.

12. Galanin N.E., Kudrik E.V., Shaposhnikov G.P. Russ. J. Org. Chem. 2001, 37, 687-688.

13. Kobayashi N., Osa T. Heterocycles 1981, 15, 675-678.

14. Thanabal V., Krishnan V. J. Am. Chem. Soc. 1982, 104, 36433650 .

15. Thanabal V., Krishnan V. Polyhedron 1983, 2, 505-507.

16. Gunter M.J., Johnston M.R. Tetrahedron Lett. 1992, 33, 17711774.

17. Sirish M., Schneider H.-J. Chem. Commun. 1999, 907-908.

18. Ghiggino K.P., Hutchison J. A., Islan D.-M. S., Araki Y., Ito O., Langford S.J., Lau V.-L., Takezaki M. Photochem. Photobiol. Sci. 2006, 5, 1150-1153.

19. Sun L., Gersdorff J.V., Sobec J., Kurreck H. Tetrahedron 1995, 51, 3535-3548.

20. Shinmori H., Osuka A. Tetrahedron Lett. 2000, 41, 85278531.

21. Noworyta K., Marczak R., Tylenda R., Sobczak J.W., Chitta R., Kutner W., D'Souza F. Langmuir 2007, 23, 2555-2568.

22. Adler A.D., Longo F.R., Finarelli J.D., Goldmacher J., Assour J., Korsakoff L. J. Org. Chem. 1967, 32, 476-476.

23. Lindsey J.S., Wagner R.W. J. Org. Chem. 1989, 54, 828-836.

24. Geier G.R., Littler B.J., Lindsey J.S. J. Chem. Soc. Perkin Trans. 2 2001, 701-711.

25. Geier G.R., Callinan J.B., Rao P.D., Lindsey J.S. J. Porphyrins Phthalocyanines 2001, 5, 810-823

26. Littler B.J., Ciringh Y., Lindsey J.S. J. Org. Chem. 1999, 64, 2864-2872.

27. Finikova O.S., Cheprakov A.V., Beletskaya I.P. J. Org. Chem. 2004, 69, 522-535.

28. Lebedev A.Y., Filatov M.A., Cheprakov A.V., Vinogradov S.A. J. Phys. Chem. A 2008, 112, 7723-7733. 